\title{
Portoan Ultra Group Members' Social Representation of Lisbon and Sport Lisboa and Benfica and Its Influence on the Discourses and Practices of the Portoan Ultra Groups and Their Members
}

Authors'contribution:

A) conception and design of the study

B) acquisition of data

C) analysis and interpretation of data

D) manuscript preparation

E) obtaining funding

\section{Daniel Seabra}

Fernando Pessoa University, Portugal

\section{ABSTRACT}

The following text relates to a more recent approach to the problem of hooliganism and the Ultra Movement. It does not focus on a broad theory aimed to explain these two phenomena, but rather concentrates on the use of concepts that are relevant for a multifaceted understanding of them. Therefore, this text is the result of an investigation carried out on the four Ultra groups who support clubs in Oporto.

It aims to demonstrate how the social representation of Lisbon as the capital of Portugal and one of its clubs, Sport Lisboa and Benfica, influences not only the discourse used by the members of the four Portoan Ultra groups and the allusive clothing that they wear, but also the practices of their own groups inside and outside football stadiums. Included in these practices are the choreographies and banners that the Ultra groups display, as well as the chants they sing.

The research also showed that the social representation mentioned above legitimizes a strong rivalry towards with Sport Lisboa and Benfica and has the capacity to suspend conflicts between the Portoan Ultra groups and unite them in collective action, sometimes violent, against the Ultra groups and members of this club.

KEYWORDS $\quad$ Ultra groups, ultra movement, social representations, violence

\section{Introduction}

The Ultra groups of football clubs emerged in Portuguese stadiums in the late 1970s, and the number increased significantly during the 1980s. In this decade, almost all the main football league clubs were supported by Ultra groups. These can be defined as

"supporters groups of a particular team, with their own name, which are concentrated in a specific area of the stadium, encouraging players through their own chants, banners and posters, synchronized clapping, waves, claxons, flares, smoke bombs, etc" (Pereira, 2002, p. 41). 
The presence of these groups continues to leave a strong mark on Portuguese stadiums through the chanting and choreographies that praise and celebrate the identifying signs of the clubs they support. In order to achieve the desired victories, the Ultra groups sometimes use the depreciation of the opponent's club to weaken the performance of its team. The Ultra groups are also well known for acts of violence and vandalism initiated by some of their members.

These groups have their origin in the Ultra movement that emerged in Italy in the late 1960s, precisely when the country was in a troubled social and political situation (Podaliri \& Balestri, 1998). The groups of fans who followed their clubs during the 1950s and 1960s found in the most extreme nature of parties a militancy model that they tried to follow when supporting their clubs (Podaliri \& Balestri, 1998). Therefore, the Ultra Movement advocates a great militancy carried out by the Ultra groups. Being an Ultra implies the presence in every game of the club and an unconditional and constant support, even if it is necessary to face adverse situations such as weather conditions or the animosity of opponents' fans.

This way of supporting a club also results from the influence of Hooliganism. In fact, the incidents that young English hooligans have caused in Italy, the active and aggressive way they support their clubs, the cohesion between group members, and their sense of territory and defense have also influenced the young Italians that founded supporters' groups (Lago \& Biasi, 1994; Podaliri \& Balestri, 1998; Roversi, 1992; Roversi \& Balestri, 2002).

Hooliganism and the Ultra Movement are therefore social phenomena with more than half a century of history. Consequently, it is not surprising that supporters' groups' peculiar expressions of support for their clubs, as well as the acts of violence in which some of their members are involved, have raised the interest of the social sciences. Throughout all of these years, there have been many investigations on these social phenomena.

\section{The main explanatory theoretical dimensions of Hooliganism and the Ultra Movement}

In short, it is possible to consider through the investigations three main dimensions in the explanation and understanding of this phenomenon. Taylor's perspective on hooliganism (1971, 1982a, 1982b), reinforced by the considerations of Critcher (1980) and Hargreaves (1986) on football as an element of the culture and values of the working class, sets up a classist dimension that tends to interpret hooliganism as a form of protest by the working classes against the loss of participation in club activities as a result of the bourgeoisification and professionalization of club officials. The violence carried out by hooligans is then understood as an attempt to restore the traditional culture of football that is associated with the working class (Taylor, 1971, 1982b). From a broader perspective, Taylor interprets the support given to the team and the longing for victory as compensation for lack of success in other spheres of social life (Taylor, 1971).

The generational dimension is another means to explain and understand these phenomena. The 1960s accentuated important social transformations that shaped the juvenile social condition. The extension of schooling led to a later introduction of young people to the labor market. As the dominance of a meritocratic ideology added productivity and economic growth to the responsibilities of workers, additional training and education for young people was encouraged, as it gave them greater opportunities to access more socially valued jobs with better pay (Clarke, 1978). This later introduction to the labor market also delayed the taking of family responsibilities.

Thus, a long transition from youth to adulthood was instituted, for which the leisure industry outlined a pattern of consumption that was expressed in the clothing worn by young people and the music they listened to. This process led to the emergence of various youth subcultures, each one of them characterized by its own values, tastes, ways of speaking and dressing, and a certain lifestyle (Clarke, 1978; Revilla, 1996). The formation of these subcultures began to denote the increasing freedom and independence of these youngsters from their parents, and the primary socialization within the family began to compete with the peer socialization occurring within these groups. Some youth subcultures established a tense relationship with the dominant society and its values, which appeared sometimes as a dynamic of rebellion and clearly differentiating defense (Costa, Tornero \& Tropea, 1996). It is therefore against this generational dimension 
that many are seeking to explain and understand hooliganism and the Ultra Movement. These are understood as manifestations of rebellion and the protest of young people against a dominant society that still does not accept them in the way that they would prefer to be accepted.

We should also consider the urban dimension that was highlighted by a group of sociologists at the University of Leicester. According to their studies, hooliganism can be explained in light of the configuration of urban communities that emerge from peripheral areas of the city where the cost of housing is lower. These areas generate up-territorial units where the disadvantaged sectors of the working class reside. The clear separation of the roles attributed to the female and male gender is another fact to consider, with the latter taking on a hegemonic position based on authority and even grounded in the ability to fight. Frequent conflicts emerge between family members, neighbors, and even groups of youths from rival neighborhoods. In addition to the incorporation of the values of a hegemonic masculinity, youngsters living in such residential areas are subject to little parental control and, therefore, to primary socialization. Socialization within the peer group that emerges from the neighborhood thus replaces socialization within the family, and many of the interactions that occur within the peer group are aggressive and dominated by the strongest youngsters.

Not surprisingly, young people who grew up under the influence of this social setting show greater tolerance towards violent behavior and also have the tendency to practice violent acts themselves (Dunning, Murphy \& Williams, 1992). Thus, hooliganism is explained by the group of sociologists from Leicester as a reproduction of aggressive behavior patterns that emerge from the social setting briefly presented above. The presence of hooligan groups is also seen as a form of representation and symbolic defense against rivals from various residential areas and respective communities to which the young people belong.

In summary, these are the three major theoretical dimensions that aim to understand and explain the problem of hooliganism and the Ultra Movement. It is also important to refer to the football stadium as a backdrop that enhances and precipitates the aggressiveness of young hooligans or members of Ultra groups. Researchers like Kerr (1994), Finn (1994), Canter, Uzzell, \& Comber (1989), or the Oxford group (Marsh, Rosser \& Harré, 1980) found that there is a context generator of tension within football, an excitement of emotions inherent in ritualistic confrontation that can precipitate the release of some repressed aggressive impulsivity from a monotonous and frustrating everyday life.

\section{Social representations and supporters' groups from the city of Oporto}

The investigation on hooliganism and the Ultra movement later evolved into a different direction. The three dimensions listed above gradually became insufficient in the understanding of the diversity of these groups, with reality highlighting gaps in each of these perspectives on the explanation of this social phenomenon. Then came the investigations of Armstrong (1994, 1998), Giullianoti (1993, 1994, 1999, 2001), Redhead (1997, 1991, 1993), Robson (2000), and King (2001), marking a new direction and theoretical approach to this issue. In addition to privileging a detailed ethnography, these investigators chose to combine multiple concepts from several authors, thus giving the phenomenon a more eclectic theoretical approach.

This text results from a similar approach and was based on an investigation carried out on the Ultra groups of Futebol Clube do Porto-Super Dragões and Colectivo Ultras 95, the Boavista Football Club Ultra group Panteras Negras, and also the Ultra group Alma Salgueirista of the club Sport Comércio e Salgueiros. This investigation was carried out over a period of six years of participant observation fieldwork and the realization of ninety semi-directive interviews and ten autobiographical narratives.

The objective of this text is to highlight the importance that the social representations of the city of Lisbon and Sport Lisboa and Benfica take on in the performance and practice of the above-mentioned supporters' groups and their members, as well as the discourses employed by them. In other words, we tried to understand the importance of social representations as structuring elements of the manifestations of Ultra groups as groups, while also taking a look at their individual members. 
A social representation is defined by Jodelet as "a socially developed and shared form of knowledge with a practical goal and contributing to the construction of a common reality within a social group" (1997, p. 53). In fact, "a representation is a physical or mental object that, for certain purposes, is supposed to replace what it represents" (Sperber, 1992, p. 36). A representation always represents something. As Vala explains, "it expresses the relationship of the subject with its object, relationship involving an activity of construction and symbolization" (2004, p. 461). The representation is thus an expression of the subject.

It becomes a social representation when it is assumed by a group of individuals, and as Vala also points out, it is "the result of the interactions and communication phenomena within a social group, reflecting the situation of the group, its projects, problems and strategies and its relations with other groups" (2004, p. 461). Functionality is another key element for a representation to be, in fact, a social representation. This means that social representations stem from communication programs that influence the language and planning that condition their practices (Vala, 2004). Given the above, Fisher's definition is of certain relevance, as it describes a social representation as "a process of perceptual and mental development of reality that transforms social objects (people, contexts, situations) in symbolic categories (values, beliefs, ideologies) giving them a cognitive status that allows you to integrate aspects of everyday life by reframing our own behaviors within social interactions" (Fisher, 1987, p. 118).

In view of this conceptualization of social representations, and retaking the objective of the present text, the terms used by the members of the Ultra groups to refer to the city of Lisbon and its inhabitants should be emphasized right from the start. Moors and Mouraria are no doubt the most frequent. Morocco or Mourolândia are also used to designate the capital of the country.

The use of these names is justified by the foundation of Portugal and the subsequent territorial expansion of the country on the Iberian Peninsula. The foundation of Portugal occurred in 1143 with the signing of a peace treaty to end the war between King Alfonso VII and D. Afonso Henriques, thus making the latter the first king of Portugal. The country's expansion process began from this date on in a North/South direction, implying the conquest of Muslim territories. It was a long process, given that total expulsion from the territory, which is the continental Portugal known today, only occurred during the reign of D. Afonso III in the year 1249 (Marques, 1998).

This history is therefore the foundation that members of Ultra groups from the city of Oporto and the rest of its inhabitants generally use in order to pejoratively reference Lisbon as Mouraria, Mourolândia, and Morocco, also nicknaming the inhabitants of the capital as Mouros - Moors. This is how the Ultra group Super Dragões legitimized the creation of a scarf with the slogan "SEEKING MOORS." This slogan also had a rope with a knot forming a gallows, and the scarf had the following words on it: "Since the date of the foundation of our glorious homeland, and inferior race mixed with us in order to obtain knowledge and other benefits. This scum should be eliminated and delivered by hand.'These words were also displayed at the stadium moments before the start of a game between Futebol Clube do Porto and Sport Lisboa and Benfica as part of a choreographed performance. During this performance, participants held up a sheet with the image of an army of Christian fighters expelling the Moors from the Portuguese territory. During the same game, the Ultra group Colectivo Ultras 95 also displayed a sheet that had an image of the international trophies won by the club, with the Moors depicted as worshiping these achievements. The words "kneel you unfaithful" were also an important part of the choreography. During another game against Sport Lisboa and Benfica and based on this same historical legitimacy, the Ultra group Colectivo Ultras 95 used a banner with the slogan "IF IT WASN'T FOR US, YOU WOULD STILL BE RIDING CAMELS."

The social representation of the elements of the Ultra groups from the city of Oporto on the city of Lisbon is not limited, however, to mere terminology or classification. It is configured by a discourse that accuses the capital of discrimination in the political, economic, social, cultural, and sports dimensions. From this results a clear prejudice towards Oporto and northern Portugal, which is the main productive capacity and strength of the country's work, based on very dynamic entrepreneurship. Inequality in terms of public and private investments as well as the distribution of resources to Lisbon at the expense of other regions of the country is a common denominator to many discourses of the members of supporters' groups from the city 
of Oporto. One of the elements of the Ultra group Super Dragões said "It's all for the South." Another pointed out: "We are the ones who work and part of Lisbon gets all the support. Because Oporto is a harderworking city than Lisbon actually is." Because of this, a member of the Ultra group Panteras Negras stressed that "the rivalry is due to the centralism that exists in Lisbon. Everything is in Lisbon. Money. Power. Everything is invested in Lisbon and Oporto is somewhat forgotten." A member of the supporter group Alma Salgueirista gave a more detailed opinion on this issue:

All the factories and everything that is industrial, everything that is hand labor is centered in the north. And what has the south got? It has the company headquarters, the headquarters of banks, the headquarters of everything. (...) I am against the north having to sustain the rest of the country and if we see, we are the least developed part of the country. We are the ones that have less support (...). It is here that work is being done but salaries there are double. I'm not saying that no one works in Lisbon because there are many people who work and even work a lot, but compared to the north, here people work a lot more. That's why we are the capital of labor.

It is important to stress that this social representation of the city of Lisbon is not confined only to the members of the Ultra groups from the city of Oporto. It is also shared by most of the population of the city of Oporto. This kind of derogatory discourse regarding the south of the country is not a recent development. In 1879, after a visit to Portugal, Ratazzi had already concluded that the inhabitants of Oporto were not fond of the people of Lisbon (Sobral, 2004). In the late nineteenth century, in a context in which racist distinctions were still acceptable, Basilio Teles, a republican intellectual, considered that the north of Portugal had very productive agriculture in relation to the south, which was uncultivated because it was in the hands of a small number of large landowners. The solution advocated by Basilio Teles was that the country's southern colonization be done by northern people. This proposal had been advanced earlier by Oliveira Martins, an intellectual and historian who lived during the nineteenth century. Basilio Teles went even further and said that the northerners were Aryans, productive farmers and warriors, while the southerners were Semites with no significant agriculture because they were lazy Arabs and Berber parasites (Sobral, 2004).

Before Basilio Teles, Alberto Sampaio advocated this representation of an ethnically divided Portugal. This dichotomous representation of Aryans in the north and Semites in the south continued with Teles and was even taken up by the writer Raul Brandão in the 1920s. In turn, António Sérgio, despite refusing the credibility of racist factors, also made distinctions between the north and south of the country in terms of geographic, human, and social differences (Sobral, 2004).

Such differentiation continues, as stated by Sobral, "to be evoked, in various ways, in the intellectual and scientific fields to handle large contrasts that tend to find correspondence in the various environments" (2004, pp. 279-280). The statements given by the members of the Ultra groups mentioned in this text provide enough evidence to suggest that this distinction is not only limited to the scientific and intellectual spheres, but is also shared by the people that use this language, thus creating the social representation of Lisbon presented above.

Whereas the football competition establishes a favorable environment for staging and concrete expression of identifiable rivalries between places, it is not surprising that the social representation of Lisbon is reflected and also exacerbates the representation of the club Sport Lisboa and Benfica, seen as the main rival to all of the Ultra groups from the city of Oporto. It is seen as the club of the former dictatorship of Salazar, with the titles achieved in the years of dictatorship owed to his power. One of the Super Dragões elements highlighted precisely this aspect, considering it "very strange that a team like Futebol Clube do Porto, which now wins frequently, did not win anything for 19 consecutive years."

Faced with such perplexity, the following explanation was given by the majority of Futebol Clube do Porto fans and by the people of Oporto: "Knowing that we lived in a period of Estado Novo, by Salazar, which later was abolished due to the revolution of " 74 . From the beginning of the " 80 s, Benfica was over. In the "70s they still won the championship a few times." Another element from Super Dragões recalled that "the results were manipulated and with evidence. Maybe the press itself was not as open as it is today and had to defend certain things that maybe now they don't hide from the public." 
The so-called "evidence" refers to some decisions made by the Portuguese Football Federation that are perceived to have been harmful to the interest of Futebol Clube do Porto and, above all, many referee decisions are considered to have been deliberately aimed to harm this club from Oporto in favor of Sport Lisboa and Benfica. The performance of the referee Innocent Calabote duringa match between Sport Lisboa and Benficaand C.U.F. in the season of 1958/1959 is regarded as the best example of how the club from Lisbon benefited; it always comes up when Futebol Clube do Porto fans evoke the history of damage that occurred to the benefit of Sport Lisboa and Benfica. Not surprisingly, it is greatly featured in the Futebol Clube do Porto Museum.

A visit to this museum will guide you through an exhibition that is structured according to a narrative that establishes a clear division between the period of the Estado Novo dictatorship and the period of democracy. During the first period, in a dark corridor, the club is presented as the victim of a political regime that benefited Benfica, which is, as stated above, considered the club of the regime. The revolution that established democracy in Portugal is properly marked by a borderline in the museum that gives access to a broad, new space in which the greatest achievements of the club are shown. It is not surprising that this narrative is reproduced and shared by the majority of the fans of Futebol Clube do Porto. One of them stated that "According to what has been said by older generations, the idea that was passed on was that Futebol Clube do Porto has always been stepped on and put aside."

This rhetoric of victimization (Bromberger, 1995) is a key component of the social representation of Lisbon and Sport Lisboa and Benfica, greatly conditioning the language used by and the practices of the Ultra groups from the city of Oporto. It is the cause of the exacerbated rivalry that can be stated in many different ways. In terms of linguistic signs, and beyond the terminology that classifies the people of Lisbon and the supporters of the two main clubs, we can find in the chants sung by the Ultra groups from the city of Oporto a language of insult, disqualification, and humiliation of the main rival club. "Shit Club," "Lisbon is shit," "people of shit," and "gay" are some classifications included in the hostile chants towards Sport Lisboa and Benfica, especially in matches against them. "Lanterns" is a frequent term used to refer to Benfica's supporters because of the association between the name of their stadium, Estádio da Luz, "the stadium of light," and the light emitted by the lamps. "Ram"s and "pigs" are other terms used by the Ultra groups to refer to Benfica's fans, although these are used less frequently.

This rivalry is still greatly visible throughout the iconography in the various materials used by the supporter groups, such as banners, flags, t-shirts, scarves, and others. The representation of a hanging rope and the words "Seeking Moors" is an example. Another well-known representation is the drawing of an eagle - the symbol of the insignia of Sport Lisboa and Benfica - being sodomized by a dragon, which is the main element of the emblem of Futebol Clube do Porto. The Anti-Lampiões expression is also widely used on the scarves of the fan clubs.

The depreciative and humiliating rhetoric used towards the main clubs of Lisbon is also evident in the choreographies presented by the Ultra groups. They are planned especially for the purpose of staging and using the colors of the club and messages and representations of support, but they also show the various dimensions of the social representation of the people from Oporto for Lisbon and its inhabitants, as has already been mentioned in this text. Other choreographies are specifically directed at Sport Lisboa and Benfica and its supporters. In a clear allusion to the so-called benefits that Benfica receives from referees, the Ultra group Colectivo Ultras 95 presented a choreography composed of eleven banners, each one of them with a picture of a referee represented as a player from the squad of Sport Lisboa and Benfica for that football season. The same group also showed another mocking and ironic choreography to the supporters of Benfica: an inflatable plastic with a birthday cake and candles commemorating ten years. The choreography was accompanied by the following message: "Congratulations Lampião. Ten years without winning a championship."

In addition to the choreographies, the rivalry is clear in the banners with messages used by the Ultra groups from the city of Oporto in football stadiums on game day with Sport Lisboa and Benfica. During 
games between the clubs from Oporto and clubs from Lisbon, there is usually a competition for communicative hegemony in the stadium between the groups that support these clubs (Bromberger, 1995).

Finally, it is important to stress that this rivalry is not confined only to a ritual or symbolic violence as proposed by the theory of the Oxford group (Marsh, Rosser \& Harré, 1980) and expressed through discourses, chants, dance routines, or messages displayed in stadiums. It leads to actual violence, which is recognized and desired by some members of the Ultra groups from the city of Oporto. Some even find in this rivalry a legitimate justification for violence and fighting between Ultra groups and even assaults on supporters of the main clubs from Lisbon. A member from the group Super Dragões justified his position: "Moors. This is Football. There are rivalries. I want them to go fuck themselves. I do not like them. I do not want to know anything about them. They are a club of shit." An element belonging to the Ultra group Panteras Negras also used a very hostile discourse to refer to Benfica. He said: "With Benfica there is no possible balance. I just do not accept stealing from them. Now beating them? No problem, I'll even help."

This kind of discourse has consequences. When Sport Lisboa and Benfica played in Oporto or nearby stadiums, the elements of the Ultra groups from the city of Oporto would gather efforts to win in physical confrontations with elements of Benfica's Ultra groups. A member of the group Panteras Negras justified their bond: "We are friends of the city of Oporto. I think this is indifferent to the club we have. When it comes to the issue between North/South I think people from Oporto are much closer than the ones in the south." In turn, a member from the Ultra group Alma Salgueirista saw in this unity of the Ultra groups from the city of Oporto an attempt to "defend our city, regardless of the club we have." The same element recalled this union between the elements of the various Ultra groups from the city of Oporto:

In the past Benfica would come here and play against Salgueiros - at Bessa or Maia Stadiums and the guys from Porto and Boavista would join us. I will never forget how the guys from Oporto would go to Maia and we would all start beating up Benfica's Ultra group. Why? We will not defend Porto the club, but our city, our pride of being tripeiros. ${ }^{1}$

In fact, there have been many situations of violence in games played between the clubs supported by Ultra groups from the city of Oporto and Sport Lisboa and Benfica that could be described here. Considering the limited extent of this text, I will briefly refer to two examples. One of them occurred outside the Boavista Futebol Club Stadium between the Ultra group Panteras Negras and members of Benfica's Ultra groups. When they were leaving the stadium, they were attacked with stones and sticks organized by members of Boavista's Ultra group. These physical clashes caused injuries and incidents but had no more serious consequences because the police intervened immediately. Some of the most violent clashes with Benfica's supporter groups occurred with the supporter group Super Dragões in the city of Coimbra. One of the members of this group confessed that such confrontations were "the most violent" and the "most pleasurable," as they were only a few people but managed to attack and drive away Benfica's Ultra groups. This person confessed that some of the group members were even armed. A member belonging to Alma Salgueirista recalled that some of these confrontations are even premeditated. Therefore, it is not surprising that after the game there were several outbreaks of violence throughout the city during the night, and the police had great difficulty putting an end to the fighting.

\section{Conclusions}

The groups that support football clubs continue to strongly attend Portuguese stadiums, guiding their actions by the Ultra movement patterns; some of their members, the ones that premeditate violent acts, could be considered hooligans.

The research carried out on the four supporter groups from the city of Oporto identified a social representation of the city of Lisbon, which is considered as a structural element of the discourses and practices of the Ultra groups from the city of Oporto. The idea that the capital of Portugal is favored in the distribution of resources and investment to the detriment of other areas of the country that produce much

${ }^{1}$ Name given to the people from the city of Porto 
more is the central element of this representation. It was confirmed that such representation on Lisbon is not recent; it was documented as early as the nineteenth century. Related to this representation on Lisbon is also the classification of Sport Lisboa and Benfica - the main rival of Futebol Clube do Porto - and its supporters. It refers to the foundation of Portugal and the expansion of the country towards the south to legitimize the use of a set of terms for the people of Lisbon and fans of that club, with Moors being the most frequent. The idea that Sport Lisboa and Benfica has always benefited from the performances of referees and the protectionism of the dictatorial political regime that lasted until April 1974 is also a key reference.

These representations are easily identifiable, not only in the language used by the members of the Ultra groups from the city of Oporto, but also in the clothing that they wear on match days and the chants and choreography that they perform when supporting their clubs against clubs from Lisbon, especially Sport Lisboa and Benfica. The investigation has also concluded that the social representation of Lisbon and Sport Lisboa and Benfica is, for some of the elements of the Ultra groups from the city of Oporto, a good enough reason to justify physical confrontations and acts of violence towards Benfica's Ultra groups and fans. The members of the Ultra groups from the city of Oporto even temporarily suspended the rivalries between themselves to unite their efforts in order to become stronger in this kind of confrontation and involvement in violence.

Notwithstanding the importance that the main theories have for understanding Ultra groups from the city of Oporto, the resort to the concept of social representation was framed in a new theoretical approach to the investigated problem and proved to be very fruitful for this study.

\section{REFERENCES}

Armstrong, G. (1994). False Leeds: the construction of hooligan confrontations. In R. Giulianotti \& J. Williams (Eds.), Game Without Frontiers: Football, Identity and Modernity (pp. 299-325). Vermont: Arena Ashgate Publishing.

Armstrong, G. (1998). Football Hooligans: Knowing the Score. Oxford: Berg.

Bromberger, C. (1995). Le match de Football. Ethnologie d'une passion partisane à Marseille, Naples et Turin /The Football Match. Ethnology of a Partisan Passion in Marseille, Naples, and Turin/. Paris: Editions de la Maison dês Sciences de L'Homme.

Canter, D., Uzzell, D. \& Comber, M. (1989). Football in its Place. London and New York: Routledge.

Clarke, J. (1978). Football and working class fans: tradiction and change. In R. Ingham, S. Hall, J. Clarke, P. Marsh \& J. Donovan (Eds.), 'Football Hooliganism' The wider context (pp. 37-60). London: Inter-Action Inprint.

Costa, P., Tornero, J. \& Tropea, F. (1996). Tribus urbanas. El ânsia de identidad juvenil: entre el culto a la imagen y la autoafirmación a través de la violência /Urban tribes. The thirst for youth identity: between image worship and selfassertion for violence/. Barcelona: Ediciones Paidós Ibérica.

Critcher, C. (1980). Football since the war. In J. Clark (Ed.), Working-Class Culture. Studies in History and Theory, (pp. 161-184). London: Hutchinson \& Co.

Dunning, E., Murphy, P. \& Williams, J., (1992). A violência dos espectadores nos desafios de futebol: para uma explicação sociológica /The violence of spectators in football matches: towards a sociological explanation/. In N. Elias, A busca da Excitação /The Quest for Excitement/ (pp. 355-388). Lisboa: Difel.

Finn, G. (1994). Football Violence. A societal psychological perspective, In R. Giulianotti, N. Bonney \& M. Hepworth (Eds.), Football, Violence and Social Identity (pp. 90-127). London and New York: Routledge.

Hargreaves, J. (1986). Sport, Power and Culture. A Social and Historical Analysis of Popular Sports in Britain. Cambridge: Polity Press.

Fisher, G. (1987). Les Concepts fundamenteaux de la psychologie sociale. /The Basic Concepts of Social Psychology/. Paris: Dunot.

Giulianotti, R. (1993). Soccer Casuals as Cultural Intermediaries. In S. Redhead (Ed.), The Passion and the Fashion(pp. 153-198). Aldershot: Avebury.

Giulianotti, R. (1994). "Keep it in the Family": An outline of Hibs' football hooligans' social ontology. In R. Giulianotti \& J. Williams (Eds.), Games Without Frontiers (pp. 327-357). Aldershot: Arena. 
Giulianotti, R. (1999). Hooligans and Carnival Fans: Scottish Football Supporter Cultures. In G. Armstrong \& R. Giulianotti (Eds.), Football Cultures and Identities (pp. 29-40). London: Macmillan Press.

Giulianotti, R. (2001). A Different Kind of Carnival. In M. Perryman, Hooligans Wars. Causes and effects of football violence (pp. 141-154). Edinburgh: Mainstream Publishing.

Jodelet, D. (1997). Les representations sociales /The social representations/. Paris: Presses Universitaires de France.

Kerr, J. (1994). Understanding Soccer Hooliganism. Buckingham: Open University Press.

King, A. (2001). Violent pasts: collective memory and football hooliganism. The Sociological Review, 49(4), 568-585. DOI: $10.1111 / 1467-954 X .00348$.

Lago, A. \& Biasi, R. (1994). Italian football fans: culture and organization. In R. Giulianotti, N. Bonney \& M. Hepworth (Eds.), Football, Violence and Social Identity (pp. 73-89). London and New York: Routledge.

Marques, A. (1998). Breve História de Portugal /Brief History of Portugal/. Lisboa: Editorial Presença.

Marsh, P., Rosser, E. \& Harré, R. (1980). The Rules of Disorder. London, Henley and Boston: Routledge \& Kegan Paul.

Pereira, L. (2002). Dicionário do Futebol. Manual do Adepto /Football dictionary. Handbook of the fan/. Lisboa: Booktree.

Podaliri, C. \& Balestri, C. (1998) The Ultras, Racism and Football Culture in Italy. In A. Brown (Ed.), Fanatics! Power, identity and fandom in football (pp. 88-100). London and New York: Routledge.

Redhead, S. (1991) Some reflections on discourses on football hooliganism. The Sociological Review, 39(3), 479-486. DOI: 10.1111/j.1467-954X.1991.tb00863.x

Redhead, S. (1993). The Passion and the Fashion. Aldershot: Avebury.

Redhead, S. (1997). Subcultures to Subcultures. An Introduction to Popular Cultural Studies. Massachusetts: Blackwell Publishers.

Revilla, T. (1996). Ultras e skinheads: La juventud visible. Imágenes, estilos y conflitos de las subculturas juveniles en España/Ultras and skinheads. The visible youth. Images, styles and conflicts of juvenile subcultures in Spain/. Oviedo: Ediciones Nobel.

Robson, G. (2000). “No One Likes Us, We Don't Care”. The Myth and Reality of Millwall Fandom. Oxford and New York: Berg.

Roversi, A. (1994). The birth of the 'ultras': the rise of football hooliganism in Italy. In R. Giulianotti \& J. Williams (Eds.), Game Without Frontiers (pp. 359-381). Aldershot: Arena.

Roversi, A. \& Balestri, C. (2002). Italian ultras today: change or decline? In E. Dunning (Ed.), Fighting Fans, Football Hooliganism as a World Phenomenon (pp. 131-142). Dublin: University College Dublin Press.

Taylor, I. (1971). "Football Mad": A Speculative Sociology of Football Hooliganism. In E. Dunning (Ed.), The Sociology of Sport. A Selection of Readings (pp. 352-377). London: Frank Cass \& Co. LTD.

Sobral, J. (2004). O Norte, o Sul, a raça, a nação - representações da identidade nacional portuguesa (séculos XIX-XX) /The North, the South, the race, the nation - representations of the Portuguese national identity (XIX-XX Centuries)/. Análise Social /Social Analysis/, 39(171), 255-284.

Sperber, D. (1992), O saber dos antropólogos /The knowledge of anthropologists/. Lisboa: Edições 70.

Taylor, I. (1982a). On the sports violence question: soccer hooliganism revisited. In J. Hargreaves (Ed.), Sport, Culture and Ideology (pp. 152-196). London: Routledge \& Kegan Paul.

Taylor, I. (1982b). Soccer consciousness and Soccer Hooliganism. In S. Cohen (Ed.), Images of Deviance (pp. 134164). Harmondsworth: Penguin.

Vala, J. (2004). Representações sociais e Psicologia Social do conhecimento quotidiano /Social representations and Social Psychology of everyday knowledge/. In J. Vala \& B. Monteiro (Coord.), Psicologia Social /Social Psychology/ (pp. 457-502)/.Lisboa: Fundação Calouste Gulbenkian. 


\section{AUTHOR'S ADDRESS: Daniel Seabra}

Fernando Pessoa University

Human and Social Sciences Faculty

Praça 9 de Abril, n. ${ }^{\circ} 349$

4249 - 004 Oporto

Portugal

E-mail: das@ufp.edu.pt

Received: 17 January 2017; Accepted: 20 February 2017 